\title{
UJI IN VIVO TAHAP PREKLINIS TERHADAP EKSTRAK BATANG PISANG (Musa paradisiaca L.) SEBAGAI ANTIINFLAMASI TOPIKAL
}

\author{
Ni Luh Kade Arman Anita Dewi ${ }^{1}$, Putu Era Sandhi Kusuma Yuda ${ }^{2}$, I Gede Agus \\ Suarnata $^{3}$, Maria Malida Vernandes Sasadara ${ }^{4}$ \\ 1,2,3,4 Fakultas Farmasi Universitas Mahasaraswati \\ Email korespondensi: armannita@unmas.ac.id
}

\begin{abstract}
ABSTRAK
Inflamasi merupakan suatu respons protektif normal terhadap luka jaringan yang disebabkan oleh trauma fisik, zat kimia yang merusak, atau zat-zat mikrobiologik. Batang pisang (Musa paradisiaca L.) selama ini sudah dipercaya secara empiris memiliki khasiat antiinflamasi topikal. Tujuan dilakukannya penelitian ini yaitu untuk membuktikan batang pisang memberikan efek antiinflamasi secara topikal in vivo di tahap preklinis. Penelitian ini merupakan penelitian ekperimental dengan menggunakan 25 ekor tikus yang dibagi menjadi 5 kelompok. Kelompok kontrol positif yang diberikan gel natrium diklofenak, kelompok kontrol negatif yang diberikan gel tanpa zat aktif, kelompok perlakuan 1 diberikan gek ekstrak batang pisang 5\%, kelompok perlakuan 2 diberikan gel ekstrak batang pisang 10\%, kelompok perlakuan 3 diberikan ekstrak batang pisang 15\%. Tiap kelompok terdiri dari 5 ekor tikus putih jantan yang sudah diinjeksi karagenan $1 \%$. Pengukuran volume radang dilakukan pada jam ke-0 sampai jam ke-4 dengan waktu pengecekan volume radang tikus setiap 1 jam dengan menggunakan pletysmometer. Data yang diperoleh kemudian di uji secara stastistik. Hasil dari penelitian ini menunjukan bahwa gel dengan kadar ekstrak batang pisang $15 \%$ dapat memberikan hasil yang baik dalam penurunan inflamasi, sedangkan gel dengan kadar ekstrak batang pisang 5\% dan $10 \%$ belum efektif digunakan sebagai antiinflamasi topikal, karena hasil yang diberikan dalam penurunan inflamasi masih belum maksimal.
\end{abstract}

Kata kunci : Ekstrak, Batang pisang, Karagenan 1\% 


\title{
IN VIVO PRECLINICAL STUDY OF THE TOPICAL ANTI-INFLAMMATORY ACTIVITY OF BANANA STEM (Musa paradisiaca L.) EXTRACT
}

\begin{abstract}
Inflammation is a normal protective response to tissue injury caused by physical trauma, chemical damage, or microbiological substances. Banana stems (Musa paradisiaca L.) have been empirically believed for their topical anti-inflammatory properties. The purpose of this study was to scientifically evaluate the in vivo preclinical anti-inflammatory activity of banana stems. This research was designed experimentally using twenty-five albino male rats which were divided into five groups: the positive control group which received sodium diclofenac gel, the negative control group which received gel basis preparation without any active ingredient, and three experimental groups which received banana stem extract gel in three different concentrations, 5\%, $10 \%$, and $15 \%$. Every five rats of every group were firstly injected with $1 \%$ of carrageenan, and the anti-inflammatory effect was evaluated every hour for 4 hours using a plethysmometer. The collected data were statistically evaluated. The results showed that banana stem extract gel with concentrations of $15 \%$ produced the best antiinflammatory effect, compared to other gel concentrations. In conclusion, the preparation of $15 \%$ banana stem extract gel can be applied as potential topical antiinflammatory preparation.
\end{abstract}

Keywords: extract, banana stem, carrageenan 1\%

\section{PENDAHULUAN}

Inflamasi merupakan suatu respons protektif normal terhadap luka jaringan yang disebabkan oleh trauma fisik, zat kimia yang merusak, atau zatzat mikrobiologik. Inflamasi sendiri

adalah usaha tubuh untuk menginaktivasi atau merusak organisme yang menyerang, menghilangkan zat iritan, dan mengatur derajat perbaikan jaringan. Tanda terjadinya inflamasi adalah pembengkakan, kemerahan, panas, dan nyeri. Ditinjau dari waktu terjadinya, inflamasi dibagi menjadi dua yaitu inflamasi akut dan inflamasi kronis (Sander, 2010).
Gaya hidup sehat dengan slogan "back to nature" telah menjadi trend baru masyarakat dunia dengan mengkonsumsi obat-obatan dari bahan alami yang relatif lebih aman dibandingkan obat-obatan dari bahan kimia sintetik. WHO menyebutkan bahwa $65 \%$ dari penduduk negara maju dan $80 \%$ penduduk negara berkembang telah menggunakan obat herbal. Dengan pola hidup masyarakat yang cenderung "back to nature", trend penggunaan herbal pun semakin meningkat. Indonesia yang mulai mengembangkan obat-obatan yang bahan bakunya 
diambil dari alam seperti obat herbal, makanan penguat daya tahan tubuh, kosmetik, bahan spa, bahan baku industri makanan dan minuman. Hal tersebut menuntut ketersediaan bahan baku tanaman obat bermutu dan berkelanjutan (Mirza et al. 2017). $\begin{array}{ccc}\text { Pisang } & \text { (Musa paradisiaca L.) } \\ \text { merupakan } & \text { tanaman yang }\end{array}$ dibudidayakan secara luas di Bali, baik sebagai tanaman pekarangan maupun sebagai tanaman di kebun. Pemaanfaatan batang pisang digunakan sebagai sayur untuk dikonsumsi, namun tidak jarang juga batang pisang sering kali dijadikan sebagai pakan untuk ternak. Pemanfaatan sebagai obat, batang pisang sudah digunakan oleh masyarakat sebagai obat penurun inflamasi, seperti inflamasi pada bisulan. Penelitian oleh Ogofure et al., (2016) menyatakan bahwa batang pisang mengandung senyawa alkaloid, tanin, flavonoid, dan steroid. Penelitian lebih lanjut terkait efek antiinflamasi dari batang pisang belum ada dilaporkan baik in vitro dan in vivo secara klinis maupun preklinis.

Berdasarkan uraian diatas, penelitian mengenai manfaat dari batang pisang (Musa paradisiaca L.) sebagai obat antiinflamasi masih belum banyak ada yang melakukan penelitian sampai saat ini. Oleh karena itu penelitian ini diharapkan dapat mengembangkan penggunaan batang pisang (Musa paradisiaca L.) yang dapat berkhasiat sebagai antiinflamasi di kalangan masyarakat, dimana selama ini batang pisang (Musa paradisiaca L.) sudah dipercaya secara empiris memiliki khasiat antiinflamasi dan alasan dilakukannya penelitian ini yaitu agar khasiat dari batang pisang (Musa paradisiaca L.) sebagai antiinflamasi didasari atas dasar penelitian dengan menggunakan uji aktivitas pada hewan coba secara topikal.

\section{METODE PENELITIAN MATERIAL}

Alat yang digunakan yaitu alatalat yang umum digunakan di dalam laboratorium, adapun alat yang digunakan dalam penelitian ini yaitu : timbangan analitik (Ohaus, USA), gunting, nampan, bejana maserasi, toples kaca, cawan porselin, batang pengaduk, kertas saring, plastik warp, aluminium foil, spuit injeksi (One Med), tabung reaksi (Pyrex), penjepit tabung, plethysmometer (Ocrchid Scientific), pipet tetes, mortir, stemper, pot, $\mathrm{pH}$ meter, lempeng kaca berukuran 20 x 20 $\mathrm{cm}$, penggaris.

Bahan yang digunakan dalam penelitian ini adalah batang pisang (Mussa paradisiaca L.), pelarut etanol, aquadest, $\mathrm{Na}-\mathrm{CMC}$ (Aloin Labora), propilen glikol (Technichem), metil paraben (Zayn Chemical) , gel natrium diklofenak (Voltaren), karagenan, etanol 90\% (Sigma Aldrich), HCL 2N (Sigma Aldrich), preaksi dragendorff (Sigma Aldrich), pereaksi mayer (Sigma Aldrich), kloroform (Sigma Aldrich), asam asetat anhidrat (Sigma Aldrich), asam sulfat pekat (Sigma Aldrich), larutan besi (III) klorida 10\% (Sigma Aldrich), pereaksi aseton (Sigma Aldrich), pereaksi asam borat (Sigma Aldrich), pereaksi asam oksalat (Sigma Aldrich), pereaksi eter (Sigma Aldrich). 


\section{Rancangan Penelitian}

Dilakukan pengambilan batang pisang (Mussa paradisiaca L.) yang didapatkan dari Desa Rendang, Kecamatann Rendang, Kabupaten Karangasem, Bali. Pengambilan bahan batang pisang yang sudah berusia kurang lebih 12 bulan atau batang pohon pisang yang sudah habis dipanen buahnya, kemudian pengambilan batang pisang $15 \mathrm{~cm}-50 \mathrm{~cm}$ dari permukaan tanah (Marhamah \& Putri 2018). Pembuatan ekstrak batang pisang dilakukan dengan metode maserasi. batang pisang segar yang dipotong kecil-kecil dimaserasi dengan menggunakan pelarut etanol $96 \%$, perbandingan bahan dan pelarut sebanyak 1:4 dan dimaserasi selama 3 hari, dengan pergantian pelarut setiap harinya. Filtrat yang diperoleh digabungkan, pelarut diuapkan menggunakan vaccum rotary evaporator pada suhu dibawah $60^{\circ} \mathrm{C}$ sampai mendapat ekstrak kental. Skrining fitokimia ekstrak etanol $96 \%$ daun katuk meliputi pemeriksaan golongan senyawa alkaloid, flavonoid, tanain, saponin, steroid \& triterpenoid (Nurcholis et al., 2018).

Pembuatan gel ekstrak batang Pisang dilakukan dengan mendispersikan basis gel Na-CMC dengan sebagian akuades yang telah dipanaskan, dibiarkan mengembang dan digerus sampai homogen. Kemudian ditambahkan ekstrak batang pisang yang telah dilarutkan dengan propilenglikol, diaduk homogen dan ditambahkan metil paraben yang telah dilarutkan dalam sisa akuades diaduk hingga homogen.

Tabel 1. Formulasi gel ekstrak batang pisang (Mussa paradisiaca L.)

\begin{tabular}{llcccc}
\hline \multicolumn{1}{c}{ Nama Bahan } & Kegunaan & \multicolumn{4}{c}{ Formulasi } \\
\cline { 3 - 6 } & & F0 & F1 & F2 & F3 \\
\hline $\begin{array}{llccc}\text { Ekstrak batang pisang } \\
\text { (\%) }\end{array}$ & Zat aktif & 0 & 5 & 10 & 15 \\
Na-CMC (\%) & Basis gel & 3 & 3 & 3 & 3 \\
Propilen glikol (\%) & Humektan & 15 & 15 & 15 & 15 \\
Metil Paraben (\%) & Pengawet & 0.2 & 0,2 & 0,2 & 0,2 \\
Aquadest (\%) & Pembawa & ad 100 $\mathrm{mL}$ & ad 100 & ad 100 & ad 100 \\
& & & $\mathrm{mL}$ & $\mathrm{mL}$ & $\mathrm{mL}$ \\
\hline
\end{tabular}

Gel yang sudah dibuat kemudian dilakukan pengujian mutu fisik berupa pengamatan organoleptik sediaan gel, pengukuran $\mathrm{pH}$ sediaan gel, pengujian daya lekat, pengujian homogenitas sediaan, pengujian daya sebar (Nurcholis et al.,2018). Setelah pengujian gel dilanjutkan dengan pengujian terhadap hewan coba. Hewan coba dalam penelitian ini adalah tikus putih (Rattus norvegicus). Sampel yang digunakan pada penelitian ini memiliki kriteria yaitu kondisi fisik yang sehat dan aktif, tikus yang berumur kurang

https://doi.org/10.33759/jrki.v3i2.129 
lebih 2-3 bulan dengan bobot tikus sekitar 160-200 gram. Teknik sampling yang dilakukan adalah probability sampling yaitu pengambilan sampel secara acak/random, dimana pengambilan sampel dilakukan secara acak sederhana (Simple Random Sampling) sehingga setiap unit populasi memiliki kesempatan yang sama untuk diseleksi sebagai sampel.

Pengujian antiinflamasi dimulai dengan dipuasakan tikus selama 18 jam, tetapi tetap diberi air minum. Uji aktivitas antiinflamasi dilakukan dengan cara menginduksi karagenan pada kaki tikus putih jantan. Tikus dibagi menjadi 5 kelompok dengan masing masing kelompok terdiri dari 5 ekor tikus yaitu, kelompok kontrol negatif (gel tanpa zat aktif), kelompok perlakuan uji (tiga konsentrasi gel ekstrak batang pisang) dan kontrol positif (gel natrium diklofenak). Kemudian masing-masing telapak kaki tikus disuntikkan secara subplantar dengan $0,1 \mathrm{ml}$ suspensi

karagenan $1 \%$. Setelah diukur dilanjutkan dengan pemberi perlakuan secara topikal sesuai degan kelompoknya. Setelah 60 menit perlakuan topikal, volume kaki kiri

tikus diukur kembali dengan menggunakan pletysmometer.

Pengukuran dilakukan setiap 60 menit selama 240 menit.

\section{HASIL DAN PEMBAHASAN}

Hasil skrining fitokimia

Ekstrak batang pisang yang diskrining fitokimia didapatkan
Data yang diperoleh diuji statistik dengan program SPSS 22 for windows, yang terlebih dahulu dilakukan uji normalitas dengan tes Shapiro-Wilk, data yang terdistribusi normal apabila nilai $\mathrm{p}$ lebih besar dari $0,05$ ( $\mathrm{p}>0,05)$ dan uji homogenitas dengan Levene Test, data dapat dikatakan homogen apabila memiliki nilai $p$ lebih besar dari 0,05 ( $p>0,05)$. Pada pengujian volume inflamasi sebelum dan sesudah diinduksi karagenan dan pengujian volume inflamasi pada jam ke 0 dan jam ke 4 di uji dengan statistika parametrik yaitu uji Paired Sample T Test, namun jika $\mathrm{p}$ lebih kecil dari 0,05 (p <0,05) untuk uji normalitas dan homogenitasnya dilakukan uji statistik non parametrik yaitu uji Wilcoxon. Kemudian pada uji selisih volume inflamasi jam ke 4 dengan jam ke 0 Data yang terdistribusi normal dan homogen dilanjutkan dengan statistika parametrik yaitu Analisi Varian (ANOVA) dengan taraf kepercayaan $95 \%$ yang diikuti dengan analisis Post Hoc Test dengan

Bonferroni, apabila data yang didapatkan tidak terdistribusi normal maka dilakukan uji Kruskal-Wallis dengan Post Hoc Mann-Whitney.

ekstrak mengandung metabolit sekunder alkaloid, flavonoid, saponin,dan triterpenoid. Hasil skrining fitokimia dari telah ekstrak batang pisang tertera di Tabel 2. hasil 
Tabel 2. Hasil Skrining Fitokimia Ekstrak Batang Pisang (Musa paradisiaca L.)

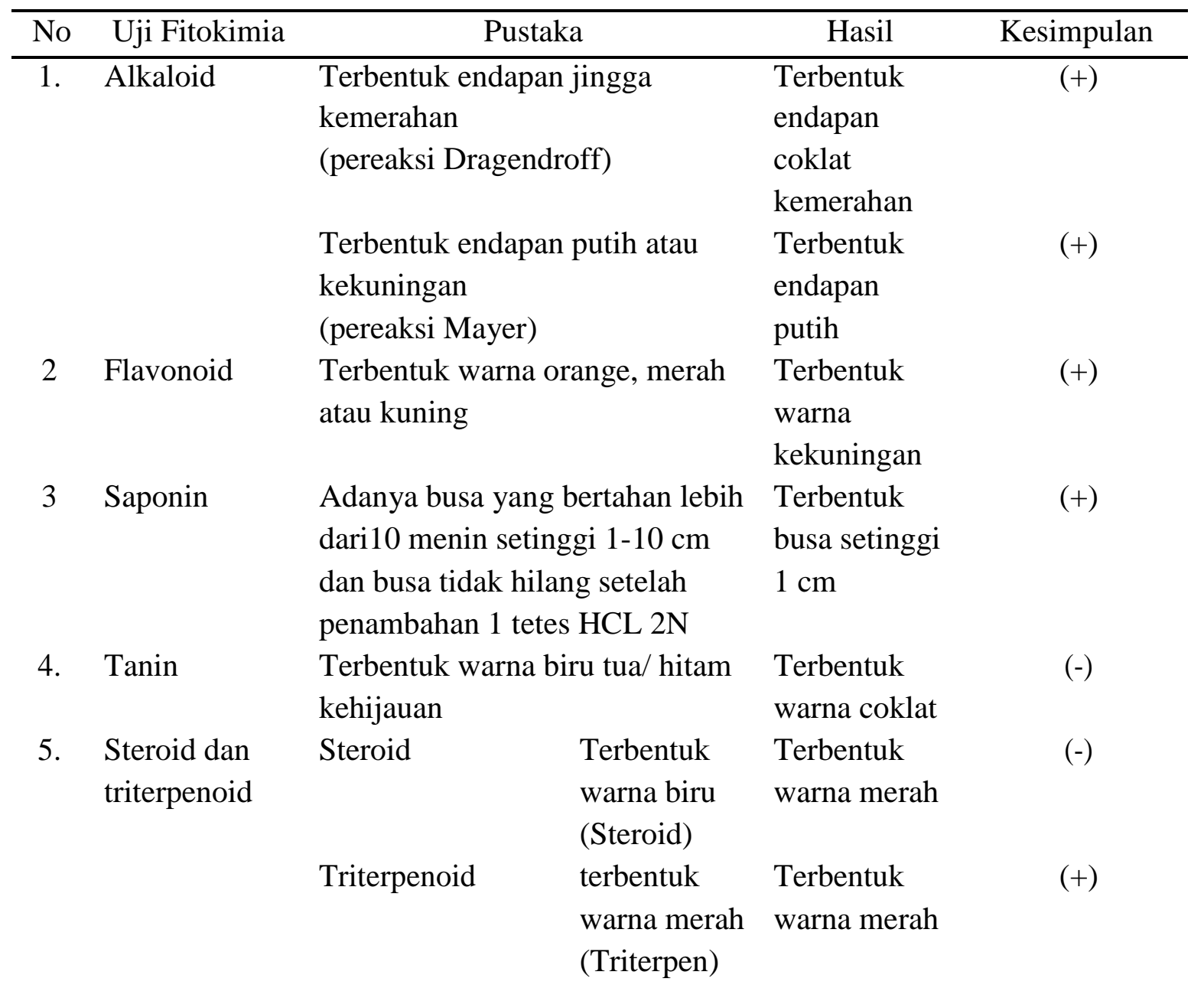

Keterangan: $(+)=$ mengandung senyawa yang dimaksud.

\section{Hasil Pengujian Mutu Fisik Gel}

Ekstrak batang pisang yang telah diskrining fitokimia dan diformulasi menjadi sediaan gel, kemudian dilakukan pengujian mutu fisik gel. Hasil pengujian mutu fisik gel tertera di Tabel 3.

Tabel 3. Hasil Pengujian Mutu Fisik Gel

\begin{tabular}{|c|c|c|c|c|c|c|c|}
\hline \multirow[t]{2}{*}{ Formula } & \multicolumn{3}{|c|}{ Organoleptis } & \multirow[t]{2}{*}{ Homogenitas } & \multirow[t]{2}{*}{$\mathrm{pH}$} & \multirow{2}{*}{$\begin{array}{l}\text { Daya } \\
\text { lekat } \\
\text { (detik) }\end{array}$} & \multirow{2}{*}{$\begin{array}{l}\text { Daya } \\
\text { sebar } \\
(\mathrm{cm})\end{array}$} \\
\hline & Wujud & Warna & $\mathrm{Bau}$ & & & & \\
\hline 0 & $\begin{array}{l}\text { Gel } \\
\text { semisolid }\end{array}$ & $\begin{array}{c}\text { Putih } \\
\text { trasparan }\end{array}$ & $\begin{array}{l}\text { Tidak } \\
\text { berba }\end{array}$ & mogen & 6 & 0,8 & 3,3 \\
\hline
\end{tabular}




\begin{tabular}{|c|c|c|c|c|c|c|c|}
\hline 1 & $\begin{array}{l}\text { Gel } \\
\text { semisolid }\end{array}$ & $\begin{array}{l}\text { Coklat } \\
\text { transparan }\end{array}$ & $\begin{array}{l}\text { Aroma } \\
\text { khas } \\
\text { ekstrak }\end{array}$ & Homogen & 6,5 & 0,8 & 5,4 \\
\hline 2 & $\begin{array}{l}\text { Gel } \\
\text { semisolid }\end{array}$ & $\begin{array}{l}\text { Coklat } \\
\text { transparan }\end{array}$ & $\begin{array}{l}\text { Aroma } \\
\text { khas } \\
\text { ekstrak }\end{array}$ & Homogen & 6,5 & 0,9 & 5 \\
\hline & $\begin{array}{l}\text { Gel } \\
\text { semisolid }\end{array}$ & $\begin{array}{l}\text { Coklat tua } \\
\text { transparan }\end{array}$ & $\begin{array}{l}\text { Aroma } \\
\text { khas } \\
\text { ekstrak }\end{array}$ & Homogen & 6,5 & 1,1 & 4,5 \\
\hline
\end{tabular}

Keterangan: Formula $0=$ gel tanpa ekstrak batang pisang, Formula $1=$ gel ekstrak batang pisang $5 \%$, Formula $2=$ gel ekstrak batang pisang $10 \%$, Formula $3=$ gel ekstrak batang pisang $15 \%$

Hasil pengujian aktivitas antiinflamasi dengan uji $\mathrm{T}$ berpasangan terhadap volume pada hewan coba (preklinis) radang rata rata tikus sebelum dan sesudah Hasil normalitas yang didapat pada di dinjeksi karagenan. Hasil pengolahan data rata-rata tikus yang belum diinjeksi menunjukan bahwa $\mathrm{p}<0,05$ dimana ini karagenan dan data rata rata tikus yang menunjukan bahwa terdapat perbedaan sudah di injeksi karagenan menunjukan yang bermakna pada tikus sebelum bahwa $\mathrm{p}>0,05$ yang menunjukan bahwa diinjeksi dan tikus yang sudah diinjeksi data sudah terdistribusi normal. karagenan. Hasil ini menunjukkan bahwa Pengolahan data selanjutnya dilanjukkan terdapat pengaruh injeksi karagenan dengan uji homogenitas yang mendapat terhadap terbentuknya inflamasi pada nilap ( $\mathrm{p}>0,05)$, kemudian dilanjutkan tikus.

Tabel 4. Perbedaan volume inflamasi tikus sebelum diberikan perlakuan dengan setelah diberikan perlakuan

\begin{tabular}{llll}
\hline Kelompok & Rata-rata jam ke-0 & Rata-rata jam ke-4 & $p$ \\
\hline Positif & 1,00 & 0,54 & 0,01 \\
Negatif & 0,87 & 0,74 & 0,11 \\
P1 & 0,90 & 0,67 & 0,01 \\
P2 & 0,90 & 0,70 & 0,01 \\
P3 & 0,94 & 0,60 & 0,01 \\
\hline
\end{tabular}

Perbedaan volume inflamasi pada kelompok pemberian ekstrak. Hal jam ke 0 dibandingkan dengan jam ke-4, sebaliknya terjadi pada kelompok negatif, melalui uji T-berpasangan, menunjukkan yaitu tidak terjadinya penurunan volume adanya penurunan volume inflamasi yang inflamasi secara signifikan pada jam ke-4 signifikan pada kelompok positif, dan sesuai dengan Tabel 4 di atas. 
Penurunan volume inflamasi pada kelompok positif dan kelompok pemberian ekstrak, perlu dilanjutkan analisa data dengan One Way Anova dan uji Post Hoc Bonferroni untuk melihat persamaan kemampuan zat dalam menurunkan inflamasi antar kelompok tersebut. Hasil analisa data tersebut menunjukkan bahwa kemampuan dalam menurunkan inflamasi antara kelompok positif dengan kelompok perlakuan 3 yaitu ekstrak $15 \%$ memiliki persamaan kemampuan dalam menurunkan inflamasi dengan nilai $\mathrm{p}>0,05$. Kemampuan penurunan inflamasi pada ketiga kelompok perlakuan ekstrak (5\%, $10 \%, 15 \%)$ memilikikemampuan penurunan inflamasi yang sama dengan nilai $p>0,05$. Gambar 1 di bawah menunjukkan perbandingan volume inflamasi pada jam ke-0 dengan jam ke-4 serta persentase penurunan inflamasi.

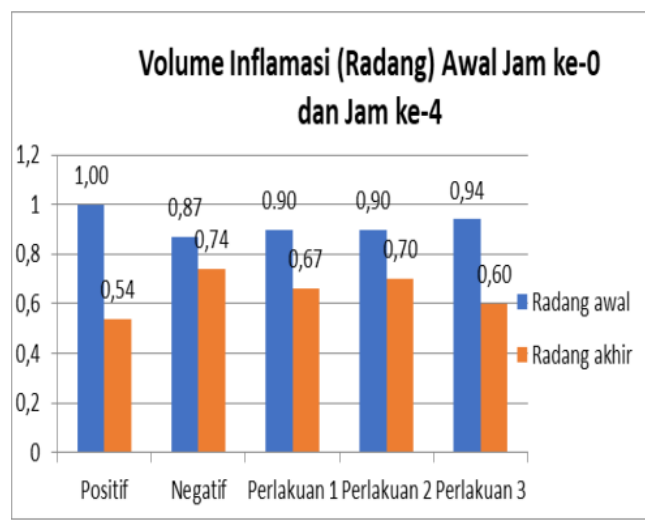

(a)

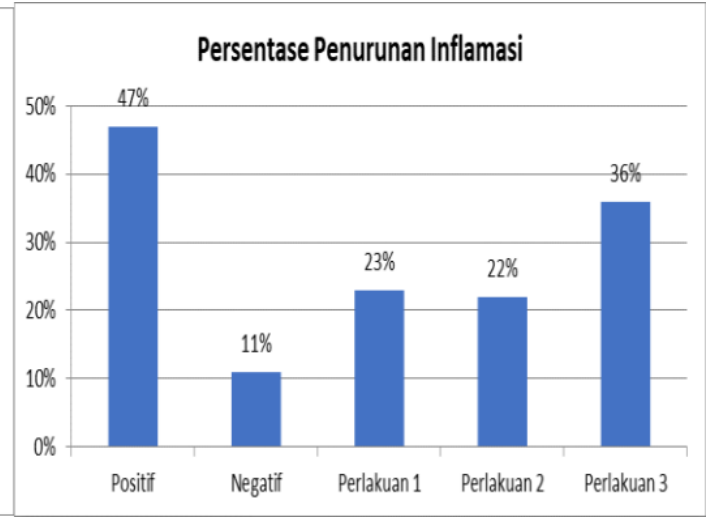

(b)

Gambar 1. (a) Volume inflamasi jam ke-0 dibandingkan dengan jam ke-4 ; (b) Persentase penurunan inflamasi

Ekstraksi sampel batang pisang (Musa paradisiaca L.) dilakukan dengan metode maserasi. Maserasi adalah suatu metode ekstraksi yang dilakukan dengan cara merendam sampel dalam cairan penyari. Cairan penyari akan menembus dinding sel atau masuk ke dalam rongga sel yang mengandung zat aktif, zat aktif tersebut akan larut karena adanya perbedaan konsentrasi antara larutan zat aktif di dalam sel dengan yang di luar sel. Larutan yang lebih pekat (di dalam sel) didesak keluar sel, masuk ke dalam larutan di luar sel. Peristiwa tersebut berulang sehingga terjadi kesetimbangan konsentrasi antara larutan di luar sel dan di dalam sel (Depkes RI, 2000). Maserasi dipilih sebagai metode ekstraksi dalam penelitian ini karena untuk menghindari rusaknya komponen senyawa akibat panas. Pelarut yang digunakan dalam proses maserasi adalah etanol $96 \%$. Etanol 96\% dipilih sebagai pelarut karena etanol merupakan pelarut universal yang dapat melarutkan senyawa-senyawa yang bersifat polar maupun nonpolar. Selain itu, etanol merupakan senyawa yang mudah menguap sehingga akan mempermudah proses penguapan pelarut. Disamping itu, ekstrak yang diperoleh 
nantinya akan diujikan ke hewan, sehingga penggunaan pelarut etanol lebih tepat karena bersifat lebih non-toksik dibandingkan pelarut methanol (Depkes RI, 2000). Batang pisang yang sudah di panen disiapkan untuk di potong kecil kecil, hal ini dilakukan untuk mengoptimalkan proses ekstraksi. Karena proses ekstraksi dipengaruhi oleh luas permukaan sampel. Hasil potongan

Uji fitokimia merupakan pengujian kandungan senyawasenyawa di dalam tumbuhan. Tumbuhan umumnya mengandung senyawa aktif dalam bentuk metabolit sekunder seperti flavonoid, tanin, alkaloid, steroid, dan saponin.

Senyawa metabolit sekunder merupakan senyawa kimia yang umumnya mempunyai kemampuan bioaktivitas dan berfungsi sebagai pelindung tumbuhan tersebut dari gangguan hama penyakit untuk tumbuhan itu sendiri atau lingkungannya. Berdasarkan hasil pengujian fitokimia pada ekstrak

batang pisang kepok (Musa paradisiaca L.), menunjukan bahwa uji flavonoid, alkaloid, saponin dan triterpenoid memberikan hasil yang positif. Hasil skrining yang ditunjukan berbeda dengan hasil skrining yang sudah pernah dilakukan oleh (Ogofure et al., 2016) yang meneliti kandungan yang terdapat pada batang pisang adalah alkaloid, flavonoid, tanin dan steroid. Variasi dari perbedaan hasil skrining tersebut dapat dipengaruhi oleh beberapa faktor seperti genetik,umur tanaman sewaktu panen, batang pisang dicampur dengan pelarut dengan perbandingan 1 : 4 dengan pergantian pelarut setiap 24 jam. Ekstrak cair yang didapat kemudian dipekatkan dengan menggunakan vaccum rotary evaporator pada suhu dibawah $60^{\circ} \mathrm{C}$ sampai mendapat ekstrak kental. Setelah ekstrak kental didapat, dilanjutkan dengan uji skrining fitokomia.

termasuk kondisi lingkungan tempat tumbuh yang terdapat nutrisi, kandungan air, $\mathrm{pH}$ yang berbeda

(Depkes RI, 2010). Setelah dilakukanya skrining fitokimia dilanjutkan pengolahan ekstrak menjadi sediaan gel, dimana ini bertujuan untuk mempermudah membandingkan antara efektivitas bahan batang pisang dengan natrium diklofenak yang sudah terdapat dalam sediaan gel.

Pemilihan tikus jantan sebagai hewan uji karena tikus jantan memiliki kestabilan hormonal dibanding tikus betina, karena tikus betina mengalami siklus masa kehamilan dan menyusui yang akan mempengaruhi kondisi psikologi hewan uji, tikus jantan tidak memiliki hormone estrogen, walaupun ada jumlahnya sangat sedikit. Sebelum digunakan untuk percobaan tikus putih di adaptasikan dengan lingkungan selama 3 minggu yang dikelompokkan menjadi lima (5) kandang masingmasing kandang terdiri dari lima (5) ekor tikus,Penguji anantiinflamasi dimulai dengan dipuasakan tikus selama 18 jam, tetapi tetap diberi air minum. Uji aktivitas antiinflamasi dilakukan 
dengan cara menginduksi karagenan pada kaki tikus putih jantan. Kelompok 1 sebagai kontrol positif yang diberikan gel natrium diklofenak, Kelompok 2 sebagai kontrol negatif yang diberikan gel tanpa ekstrak batang pisang dan kelompok 3,4 dan 5 sebagai kelompok perlakuan yakni diberikan gel ekstrak batang pohon pisang dengan konsentrasi ekstrak yang berbeda yaitu 5\%, 10\%, dan $15 \%$. Metode uji yang digunakan adalah metode paw edema, edema

buatan ditimbulkan dengan menginjeksikan karagenan $0,1 \%$ dalam $10 \mathrm{ml}$ larutan $\mathrm{NaCl}$ sebanyak $0,1 \mathrm{ml}$ secara subplantar pada telapak kaki tikus injeksi karagenan, menyebabkan trauma akibat radang yang ditimbulkan oleh karagenan. Karagenan sebagai penginduksi radang memiliki beberapa keuntungan antara lain tidak meninggalkan bekas, tidak menimbulkan kerusakan jaringan, dan memberikan respon yang lebih peka terhadap obat antiinflamasi dibandingkan dengan senyawa iritan lainnya. Udem yang disebabkan oleh karagenan bisa bertahan selama 6 jam dan berangsur-angsur berkurang dalam waktu 24 jam (Sukmawati et al., 2015). Tiap tikus diuji dengan cara memasukkan sampai tanda batas pada alat plesthymometer dan diukur volume peradangan pada jam ke 0, 1, 2, 3, 4 . Data yang diperoleh kemudian di uji secara stastistik menggunakan program SPSS 22 for windows.

Pengolahan data awal dilakukan uji terhadap data tikus yang belum di injeksi karagenan dan tikus yang sudah di injeksi karagenan. hasil pengolahan menunjukan bahwa $\mathrm{p}<0,05$ dimana ini menunjukan adanya penambahan valume radang pada kaki tikus yang sudah di injeksi karagenan. Hal ini membuktikan bahwa injeksi karagenan yang dilakukan sudah memberikan efek terhadap kaki tikus. Pengolahan data dilanjutkan dengan pengujian antar kelompok tikus yang di bandingkan volume radang pada jam ke-0 dan radang pada jam ke-4. Dilakukan uji normalitas pada masing masing kelompok tikus, semua kelompok tikus jam ke-0 dan jam ke-4 memiliki nilai $\mathrm{p}$ > 0,05 yang menunjukan bahwa semua data sudah terdistribusi normal. Pengujian dilanjutkan dengan Anova, pada jam ke-0 menunjukan nilai $\mathrm{p}>$ 0,05 yang menunjunjukan bahwa tidak ada kelompok yang memiliki perbedaan yang bermakna, pada jam ke-4 menunjukan nilai $\mathrm{p}<0,05$ dimana pengujian menunjukan bahwa ada perbedaan bermakna antar kelompok tikus, perbedaan pada jam ke-4 ini menunjukan adanya pengaruh atau efek dari perlakuan yang diberikan kepada tikus. Untuk melihat kelompok apa yang memiliki perbedaan bermakna dan tidak memiliki perbedaan bermakna. Dilakukan uji $\mathrm{T}$ berpasangan, hasil pengujian kelompok positif, P1, P2, P3 menunjukan hasil $\mathrm{p}<0,05$ yang menunjukan adanya perbedaan yang bermakna hal ini menunjukan bahwa kontrol positif, perlakuan 1, perlakuan 2, dan perlakuan 3 memiliki efek sebagai penurun inflamasi. Sedangkan hanya kontrol negative yang memiliki hasil $\mathrm{p}>0,05$ yang menunjukan bahwa kontrol negatif tidak memberikan efek terhadap penurunan inflamasi.

https://doi.org/10.33759/jrki.v3i2.129 
Pengolahan data dilanjutkan
dengan pengujian antar kelompok
tikus yang di bandingkan selisih
volume radang pada jam ke-0 dan jam
ke-4, data ini menunjukan jumlah hasil
dari penuruna radang yang didapatkan.
Hasil volume peurunan didapatkan
dengan melakukan pengurangan jam ke-4 dikurang dengan jam ke-0. Dilakukan uji normalitas pada masing masing kelompok tikus, semua kelompok tikus memiliki nilai $\mathrm{p}>0,05$ yang menunjukan bahwa semua data kelompok tikus sudah terdistribusi normal. Pengujian dilanjutkan dengan uji One Way Anova menunjukan nilai $\mathrm{p}<0,05$ dimana pengujian menunjukan bahwa ada perbedaan bermakna antar kelompok tikus, hasil ini menunjukan adanya perbadaan jumlah volume radang yang dapat diturunkan tiap kelompok tikus perlakuan tersebut berbada. Setelah pengujian One Way Anova dilanjutkan dengan pengujian Post Hoc Bonferroni, pengujian ini bertujuan untuk melihat kelompok mana yang memiliki jumlah penurunan radang yang bermakna dan tidak bermakna. Dari data pengujian dapat dilihat bahwa kontrol positif memiliki hasil yang tidak beda bermakna dengan kelompok perlakuan 3, hal ini

menunjukan bahwa kelompok perlakuan 3 yang menggunakan gel ekstrak batang pisang $15 \%$ memiliki efektivitas yang sebanding dengan kelompok positif yang menggunakan gel natrium diklofenak, sedangkan

kelompok perlakuan 1 yang menggunakan gel batang pisang 5\% dan kelompok perlakuan 2 yang menggunakan gel ekstrak batang pisang $10 \%$ hasil yang diberikan belum dapat menunjukan efektifitas yang sebanding dengan kontrol positif, namun pada hasil pengujian gel formula 1 dan gel formula 2 mendapat hasil yang tidak berbeda bermakna dengan gel formula 3, yang dimana menunjukan bahwa gel formula 1 dan gel formula 2 memiliki kemampuan

penurunan inflamasi, namun kemampuan penurunan inflamasinya lebih rendah dibandingkan gel formula 3.

Berdasarkan uraian hasil penelitian dapat dinyatakan bahwa

ekstrak batang pisang dapat menurnkan inflamasi yang terjadi kepada tikus. Namun untuk efektivitas yang ditunjukan pada kadar gel ekstrak batang pisang 5\% dan gel ekstrak batang pisang $10 \%$ masih belum efektif, karena pada kadar dosis ini ekstrak batang pisang belum mampu untuk disandingkan dengan natrium diklofenak. Namun pada gel ekstrak batang pisang kadar $15 \%$ menunjukan hasil yang baik, dimana ekstrak pada kadar $15 \%$ efektif dalam penurunan inflamasi pada kaki tikus, hasil ini dapat dilihat dari hampir sebandingnya penurunan inflamasi gel ekstrak $15 \%$ dengan natrium diklofenak. Dalam mencapai efektifitas yang diharapkan, dosis dari ekstrak sangat berpengaruh terhadap jumlah penurunan inflamasi yang didapat.

Kemampuan gel ekstrak batang pisang dalam penurunan inflamasi tidak terlepas dari kandungan metabolit yang terdapat pada ekstrak 
batang pisang. Berbagai kandungan yang terdapat dalam ekstrak batang pisang yang sudah teridentifikasi oleh peneliti meliputi senyawa alkaloid, flavonoid, saponin, serta triterpenoid, dari perbandingan dengan sumber lain dapat dilihat perbedaan kandungan yang didapatkan dalam skrining fitokimia tumbuhan (Micania cordata) yang terdapat dalam jurnal (Harnis et al., 2018), dalam jurnal tersebut didapatkan hasil skrining flavonoid, saponin, dan tanin. Perbandingan dengan sumber lain juga dapat dilihat perbedaan kandungan yang didapatkan dalam skrining fitokimia tumbuhan (Pistacia alantica D.) yang terdapat dalam jurnal (Amri et al., 2018), dalam jurnal ini didapatkan hasil skrining fitokimia berupa senyawa tanin, terpenoid, dan flavonoid. Dari tiga jurnal yang didapatkan perbandingan jurnal bisa dilihat bahwa kandungan metabolit yang sama dari ketiga jurnal tersebut adalah kandungan flavonoid. Dari hasil ini dapat ditunjukan bahwa senyawa flavonoid sangatlah berpotensi digunakan sebagai antiinflamasi. Flavonoid merupakan senyawa polifenolik yang berasal dari tanaman. Lebih dari 4000 jenis

flavonoid yang sudah dapat diindentifikasi dan dikategorikan menjadi flavonol, flavon, katekin,

flavonon, antosianidin, dan isoflavonoid. Flavonoid memiliki berbagai efek biologis terhadap sistem sel mamalia, flavonoid telah banyak terbukti sebagai antimikroba, antivirus, atioksidan, antihipertensi, dan sebagai antiinflamasi (Mohamed et al., 2014).
Senyawa metabolit sekunder yang berhasil teridentifikasi pada ekstrak batang pisang juga memiliki potensi sebagai antiinflamasi, seperti: alkaloid yang sudah dilakukan

penelitian tentang mekanisme penurunan antiinflamasi, dimana senyawa alkaloid memiliki mekanisme kerja penurun inflamasi dengan

menghambat siklooksigenase (Rachmania et al.,2018). Saponin mampu berinteraksi dengan banyak membran lipid seperti fospolipid yang merupakan pemicu prostaglandin, serta mampu menghambat terbentuknya mediator-mediator inflamasi (Hasim 2019). Berbagai macam kandungan metabolit sekunder yang terdapat dalam ekstrak batang pisang dapat membantu dalam proses penurunan inflamasi yang terjadi.

\section{KESIMPULAN}

Berdasarkan dari penelitian yang telah dilakukan dapat disimpulkan bahwa ekstrak batang pisang (Musa paradisiaca L.) memiliki kemampuan sebagai antiinflamasi topikal. Gel dengan kadar ekstrak batang pisang $15 \%$ dapat memberikan hasil yang baik dalam penurunan inflamasi, sedangkan gel dengan kadar ekstrak batang pisang $5 \%$ dan $10 \%$ belum efektif digunakan sebagai antiinflamasi topikal, karena hasil yang diberikan dalampenurunan inflamasi masih belum maksimal. Diharapkan untuk melakukan penelitian lebih lanjut mengenai potensi dari bagian-bagian lain tumbuhan pisang yang dapat digunakan sebagai antiinflamasi. Serta penelitian lebih lanjut mengenai mekanisme penurunan 
inflamasi dari metabolit sekunder yang terkandung dalam batang pisang.

\section{UCAPAN TERIMAKASIH}

Pada kesempatan ini, peneliti ingin mengucapkan terima kasih kepada berbagai pihak yang telah membantu terwujudnya penelitian ini, diantaranya Pimpinan Fakultas Farmasi Universitas Mahasaraswati dan rekan-rekan dosen yang telah membantu kelancaran penelitian ini.

\section{DAFTAR PUSTAKA}

Amri, O., Zekhnini, A., Bouhaimi, A., Tahrouch, S., \& Hatimi, A. (2018).

Anti-inflammatory activity of methanolic extract from Pistacia atlantica desf. leaves. Pharmacognosy Journal, 10(1).Departemen Kesehatan Republik Indonesia., 2000, Parameter Standar Umum Ekstrak Tumbuhan Obat, Departemen Kesehatan RI, Jakarta.

Departemen Kesehatan Republik Indonesia..(2010).Parameter Standar Umum Ekstrak Tumbuhan Obat. Departemen Kesehatan RI :Jakarta.

Harnis, Z. E., Sitorus, P., \& Rosidah, R. (2018). Phytochemical Screening And Anti-Inflammatory Activity Of Fractions From Sambung Rambat (Micania cordata) Leaf. Asian J Pharm Clin Res, 11(8), 199-201.

Hasim, H., Arifin, Y. Y., Andrianto, D., \& Faridah, D. N. (2019). Ekstrak Etanol Daun Belimbing Wuluh (Averrhoa bilimbi) sebagai Antioksidan dan Antiinflamasi. Jurnal Aplikasi Teknologi Pangan, 8(3), 8693.Marhamah \& Putri, IW., 2018, Efektivitas Ekstrak Batang Pisang Kepok (Musa x paradisiaca Linn.)

Terhadap Pertumbuhan Bakteri Streptococcus pyogenes. Jurnal Analisis Kesehatan, vol. 7, no. 1.

Mirza, M., Amanah, S., \& Sadono, D. (2017). Tingkat Kedinamisan Kelompok Wanita Tani dalam Mendukung Keberlanjutan Usaha Tanaman Obat Keluarga di Kabupaten Bogor, Jawa Barat. Jurnal Penyuluhan, 13(2), 181193.Mohammed, MS, Osman,WJA, Garelnabi, EAE, Osman, Z, Osman, B, Khalid, HS \& Mohamed, MA., 2014, Secondary Metabolites as Antiinflammatory Agents, The Journal of Phytopharmacology, no. 3, vol. 4, pp. 275-285.

Nurcholis, I. A., Yusriadi, Y., \& Sulastri, E. (2019). Aktivitas Antiinflamasi Gel Ekstrak Rumput Mutiara (Ordelandia corymbosa L.) Pada Tikus (Rattus norvegicus L.) Yang Diinduksikan

Karagenan. Biocelebes, 13(1).

Ogofure, A. G., \& Emoghene, A. O. (2016). Evaluation of proximate, phytochemical and antibacterial properties of the pseudostem and hand of plantain (Musa paradisiaca). Nigerian Journal of Agriculture, Food and https://doi.org/10.33759/jrki.v3i2.129 
Environment, 12(2), 19-26.Rachmania, RA, Zikriah, R, Hariyanti, \& Soultan, A., 2018, Studi In Silico Senyawa Alkaloid Herba Bakung Putih (Crinum Asiaticum L.) pada Penghambatan Enzim Siklooksigenase (COC). Jurnal Kimia Valenci, vol. 4, no. 2, pp. 124136.

Sander, M. A. (2017). Atlas Berwarna
Patologi Anatomi.

Sukmawati, S., Yuliet, Y., \& Hardani, R. (2015). Uji aktivitas antiinflamasi ekstrak etanol daun pisang ambon (Musa paradisiaca L.) terhadap tikus putih (Rattus norvegicus L.) yang diinduksi karagenan. Jurnal Farmasi Galenika (Galenika Journal of Pharmacy)(e-Journal), 1(2), 126-132. 